\title{
STATE LAW PROTECTION AGAINST OUTSOURCING WORKERS BASED ON JUSTICE PERSPECTIVE
}

\author{
Kolahman Saragih \\ Doctoral Program of Law Science \\ University of North Sumatera \\ Medan, Indonesia \\ rajatalun.simalungun@yahoo.com
}

\author{
Ningrum Natasya Sirait \\ Doctoral Program of Law Science \\ University of North Sumatera \\ Medan, Indonesia \\ ningrum.sirait@gmail.com
}

\begin{abstract}
Outsourcing workers in Indonesia face some problems although there is law Number 40 year 2007 concerning Corporation and Law Number 13 year 2003 concerning Labor. The problem regarding the condition of Outsourcing workers especially relate with Protection and Social Insurance from the State. This study used juridical normative research with multi and interdicipline approaches.

There were two conclusions at the end of the research. First, Law concerning Labor could not provide social insurance for the outsourcing worker. Secondly, the outsourcing worker would have justice and legal certainty through systems such as "Agreement in fixed time" (PerjanjianKerjaWaktuTertentu or PKWT) or Agreement with unfixed time (PerjanjianKerjaWaktuTidakTertentu or PKWTT) in writing models. These models consist of rights and duties of the employer and the employee such as started and end dates of work, period of time, salary, and work burden, social insurance, additional payment, vacation, holiday extra money, pension and the dispute resolution mechanism.
\end{abstract}

Key Words: Outsourcing Worker; State; Protection; Justice;

\section{INTRODUCTION}

Justice is one of the basic humanitarian values that become the aspirations and desires of every person. The 1945 Constitution of Republic Indonesia recognizes, protects its freedom and honor, and its blood and property by upholding truth and justice as defined in Article 27 section (2) The 1945 Constitution of Republic Indonesia states that "every Indonesian citizen is entitled to decent work and livelihood for humanity". This statement can cite that the state is responsible to give the right to work and decent living to every citizen of the state, as this is also guaranteed in the Law No. 80 of 1957 on the Ratification of ILO Convention No. 100 concerning Wages for Men and Women for Work of Equal Value, (State Gazette No. 171 of 1957). [1]

Working is certainly a human's way to gain dignity and improve welfare even when faced with the reality of limited employment. The uprightness of truth and justice will certainly provide peace and security and trust between the government and the people or vice versa, besides fostering wealth and prosperity. This will affect each party to work more optimally, devote themselves to the interests of the state and its inhabitants without the fear of being blocked or obstructed. [2]

Allah SWT, as cited in the Al-Qur'an, commands man to be fair, it includes in determining decisions and giving witnesses. Justice in law is justice that can bring peace, happiness and natural happiness to the society. Justice in the law can be seen clearly in practice, if the judge's decision imposed by law enforcement officers has been able to provide a sense of tranquility, happiness and tranquility for the community and able to grow people's opinion that the judge's judgment is fair and fair. This will give people confidence in the existence of court institutions that defend the rights and punish the offenders. If such a condition has been achieved, it will help prevent the onset of vigilant practices that are often perpetrated by people who are dissatisfied with the judge's decision.

Being a worker through a company Outsorcing (Outsourcing) is one of the alternative opportunities taken by some citizens both in the country and abroad to improve their prosperity. Even through the Indonesian Workers Resource (TKI) sent abroad, the country gets foreign exchange for the existence of the TKI. Through various regulations, the government has created a legal tool for the development of industry through the world of business related to the world of labor. Law No. 39 of 2004 on the Placement and Protection of Indonesian Migrant Workers Abroad, and Law No. 13 of 2003 on Manpower. Both Labor Laws are government regulations to protect workers' rights as they should. On the other hand, entrepreneurs are also working to capture every opportunity of Outsourcing employment business in particular, either through the use of various business facilities provided by the government or through internal efforts to perform operational cost efficiency. [3].

According to SahatDamanik, one of the regulations that has been under scrutiny lately is Law no. 13 Year 2003, about Manpower. Although the law is largely the extension of the 
old Manpower Act, the contents of several new provisions involve much debate concerning the interests of labor (labor) and employers. One of the topics or substances set forth in Law no. 13 of 2003 is the provision on Outsorcing, which in the previous labor regulation is not regulated. However, although Outsorcing is not regulated in the previous legal regulation, in practice the business has been implemented by the middlemen. [4]

Arrangement of provisions on outsorcing in Law no. 13 In 2003, on the one hand has opened up opportunities for new companies engaged in outsourcing labor services (outsourcing), and on the other hand has enabled companies that have stood for efficiency through the products utilization or certain services that are directly related to the main business of the provider company.

Although the regulation has opened up new business opportunities and efficiencies for companies that are operating, on the other hand, there are those who feel threatened. They are laborers who have worked on parts that are not directly related to the main business of the company, such as Security Unit, Cleaning Service, Catering, Labor Transportation and Mining / Petroleum Workers Assistant in accordance with Article 66 Law no. 13 Year 2003 on Manpower. Because, legally, these five types of work are Production Support Works. This means that this work can be given to the providers service or called Outsorcing. In facts, the practice in the field, not a few providers of work companies (factory) provide work to Outsorcing although directly related to the production business.

Any regulation done by the government always causes the pros and cons. Hence, when the impact generated more profits to the community a lot, then the smaller interests must be set aside. In this case the government should really determine the attitude wisely.

Basically, in line with the development of investment, in line with the development of the type of outsorcing business, it is the responsibility of the government to conduct supervision, and provide sanctions and legal action to outsorcing companies that tend to make sense and harming the workers.

\section{PROBLEMS}

Based on the previous background, the formulation of the problem is as follows :

1. How is the state law protection against Outsorcing Workers in the Employment Law Regulations perceived from the perspective of justice?

2. How is the form of law protection against Outsourcing Workers viewed from the perspective of justice?

3. What is the model of legal relationship between Outsourcing Worker and Employer?

\section{RESEARCH METHODS}

This research is a joint research between qualitative and quantitative research and also conduct normative law research. Research data used the form of secondary data consisting of (a) primary legal materials in the form of regulation and (b) secondary law material that were book and journals through literature study and document study. Data analysis is done by conceptual approach and statue approach. The theory used in this research was stakeholder theory of modern corporation.

\section{RESEARCH RESULT AND DISCUSSION}

A. Law Protection Substance Against Outsorcing Workers In Employment Law Regulations Viewed from a Justice Perspective

- State's responsibility against outsourcing workers

Given the outsorcing workers so unstable, so in practice in the field tends to be misused by the Employment Service Company, the role of the State in this case the Government is very important to conduct integrated and systematic monitoring. In Chapter XIV, Articles 176, 177, until Article 181 of Law no. 13 of 2003 on Manpower stated "Labor inspection is conducted by labor inspectors who have tendency and independency to ensure the implementation of labor legislation regulations".

Chapter XV, Article 182 of Law no. 13 of 2003 on Manpower stated "Investigation". In addition to investigators of the Police officers of the Republic of Indonesia, as well as to the employment of inspectors may be given special powers as civil servant investigators in accordance with applicable laws and regulations. Then in Chapter XVI, Article 183, Law no. 13 Year 2003, after investigation by the civil servant investigator in this case the investigator who authorize at the local Office of Manpower, then Article 183 provides criminal sanctions and administrative sanctions to the violation, in this case of the perpetrators of outsorcing companies.

Outsorcing workers, in the life of the nation-state of Indonesia, actually have a very important social role, but the strata class inhibits the publication of the workers' social movements to engage in cultural movements, consolidate the power of political bargaining power and shape their habitats and way of life. Only outsourcing workers are the only jobs that are weak and do not have the power of reality in Indonesia. Outsorcing workers are usually tied with a unilateral work agreement. It is almost the same as workers who work permanently and is the lowest class in the system economic and social conditions in Indonesia, the social presence of outsourcing workers is like the air which is invisible but can be perceived and very important. Throughout its history, outsourcing workers in Indonesia have never formed professional associations. The association's idea once appeared on the comedy level in the 70s with its chairman Zus Doris Callebout who got sponsorship from DjalalGendut through the movie 'InemPelayanSeksi'. [5] 
Outsorcing workers have tremendous social influences in the life history of the Indonesian nation, this can be seen from various names attributed to this people, from contract laborers, wholesalers, crude workers, and casual laborers (BHL), houseboys and others etc. This type of job outsorcing is a type of work that is typical, so even if the juridical fulfill the elements of labor or labor in general as described provisions of the Manpower Act, but Outsorcing Workers have its own peculiarities, in addition to work outside the core business (core business) a company, or supporting activities that are not directly related to the production process, then the legal relationship between the outsourcing worker and the provider of employment is completely absent. Other specificity is the work that can be outsorcing consists of five types of activities, among others: cleaning services, business caterer for food, security, supporting services in mining and petroleum, as well as efforts to provide freight for workers/laborers.(6)

The Government of Indonesia is perceived as failing to protect some of the outgoing workers in Indonesia from unilateral layoffs, low wages, very high working hours, no social security, and unknown career outsourcer career ladder, so the fate of the outsourcing workers is like grass that grows on the rock, "unwilling to live, unwilling to die". Many companies are now recruiting their workforce through employment service providers or better known as outsorcing. Recently, various companies that use outsorcing services increase so high that the word "outsorcing" seems familiar in our ears. Unfortunately, even so, there are still many candidate workers who do not understand correctly, what exactly is the labor outsorcing itself. [7]

- What is outsorcing?

When referring to Law no. 13 Year 2003 on Manpower, Outsorcing is known as a provider of labor services as set forth in chapters 64, 65 and 66. In the world of Industrial Psychology, employee outsorcing noted is a contract employee supplied from an outsourcing provider., outsorcing companies provide the type of work that is not directly related to the core business of the company and does not care about the career ladder. Such as cleaning servise, catering, security, supporting business in mining and petroleum, as well as effort of providing transportation of worker / laborer. But now, the use of outsorcing extends to various lines of corporate activity. By employing outsourcing labor, the work provider (factory) does not have to bother to provide facilities such as meals, transport, pudding, social security (Jamsostek / BPJS), and so forth. It is due to the fact that the responsible party is the company outsorcing itself. Although giving profits to the company, this system is detrimental to worker / labor outsorcing. In addition to no career, cheap wages, long hours, easy layoffs and tends to get unfair treatment from employers (employers) such as salary deductions from the parent company. The percentage of pay cuts can reach 30 percent, as a service for companies outsorcing. Unfortunately, not all workers / outsorcing workers know how much the deduction of salary taken by the company outsorcing for services to provide work in other companies.
- Outsourcing Working System

The outsourcing labor recruitment system is in fact not much different from the labor / worker recruitment system in general. The difference is that these workers are recruited by the employment services company, not the companies that need their services directly. Later, by the employment company, workers will be sent to other companies (clients) who need it. In this working system, usually outsourcing service providers make payments first to workers / laborers. Furthermore, they charge their customers' service companies. Outsourcing workers / laborers usually work on contract, with outsourcing service providers, not with service companies. Therefore, we can always expect for every citizen who intend to find a job via outsorcing company, before signing a work agreement, it helps you to pay attention to a number of points listed in related agreements such as:

1. Period of agreement, make sure the employment agreement in accordance with the period of service offered. An employment agreement between an outsourcing employee and a service provider company usually follows the term of the cooperation agreement between the service provider and the employer. It is intended what if the employer company wants to terminate its cooperation with the service provider company, at the same time, the employment contract also ends between the employee and the employer company. 2. The identity of the parties ranging from the workers, the service providers of the workers / laborers and the employer (factory). This is intended to facilitate the memories of the parties what if there is a difference of opinion in the future. 3. Wage / salary, wage scale must be clear and in accordance with minimum wage standard based on Governor's Decree in every Province in Indonesia which is named Provincial Minimum Wage (UMP), and Minimum Wage of City / District Sector (UMKS). In the employment, agreement must be listed the number of wages per month, and working hours per day 7 hours.

Types of occupations There are five types of work that are set out in the chapter 64, 65, 66 Act no. 13 of 2003, among others, Cleaning servise, Catering, Security, Business support branching and petroleum, and business provider of transportation workers / laborers. Thus, only the five types of this work that can be outsorcing, but the work directly related to the production process is not justified for the outsorcing .. - The Harmonious Paradigm.

The peaceful and peaceful situation in a family or household is the main prerequisite for the realization of a harmonious condition in the family life. Peace and serenity within the family require social intercourse in the context of friendship among family members in the household. Between family members with each other is a true friend in every way, in terms of harmonious relationships between outsourcing workers with outsourcing business actors and provider companies. These three elements are very important always make friendly approaches and to mutually benefit each other. The way to establish a harmonized relationship between Outsorcing Workers (Workers), with Outsorcing Companies 
and Employer Company, is that each party must perform the following steps:

1. Mutual understanding; Understanding each other between the outsourcing workers and their employers, and the employer (factory). There must be built on the awareness and understanding that each side has its own advantages and disadvantages. Each side has different backgrounds and interests.

2. Communication; Communication in question is a cool and friendly communication, empathy and sympathetic relationship between the Employer and the employee, not a rigid and tense communication. Love each other, receive each other and always give.

- Principles of Agreement

As described above, the legal relationship between outsourcing orkers and offenders in Indonesia, especially in the regions and some in urban areas, is generally based on unilateral employment agreements. Where such agreements are more inclined to the norms in favor of the employer's interests. While the legitimate requirements of an agreement as defined in Article 1320 of the Civil Code determine the four terms of validity of the agreement, namely:

1. Agree to those who bind themselves

2. The ability to create an engagement

3. A certain thing

4. A lawful cause.

Subekti provides limit distinction betweenengagement and convenantthat the Engagement is: "An engagement is a legal relationship between two persons or two parties, on the basis of which one party has the right to claim on the other, and the other shall be obliged to fulfill the demand".

While the Convenant is: "A convenant is an event in which a person promises to another or where the two men promise to do a thing".

Chapter IX, Article 50 of Law No. 13 Year 2003 On Manpower has on the working relationship between workers and employers. Article 50 states: "The working relationship occurs due to an employment convenant between employers and workers/laborers". And Article 50 to Article 66 of Law no. 13 of 2003 regulates working relationshis through the convenant between employers and workers/laborers.

B. Forms of legal protection against outsourced workers viewed from the perspective of justice?

\section{- $\quad$ Protection of Basic Rights}

Right is a condition inherent in human life. It is owned by a person and its exsistence can be enjoyed. If someone has the right, then someone will use their rights freely without any intervention or threat from any party. To protect a person of truly having the freedom to do his/her right and the protection of a person to enjoy his/her rights, then the existence of human rights is agreed (Human Rights). This Human Rights has been regulated since December 10, 1948 in the Universal Declaration of Human Rights (DUHAM), which contained the political civil rights and economical rights, as well as social and cultural rights. Then in 1966, the United Nations created two separate instruments: International Convenant on political civil rights and International Convenant on the economic, socio-cultural rights. [8]

Workers' rights are different from workers' human rights. Human rights are rights that are given by God as nature inherent in every human being as the consequence of being a human, while the basic rights of labor are the right inherent in each worker as the consequence of being a worker. Labor rights exist as a consequence of (result) a working relationship between laborers and employers/agencies. Labor rights in Indonesia are regulated in Law No. 13 of 2003 on employment. [9]

There are at least 8 basic rights of workers, they are:

1. Workers' basic rights in working relationship

Every worker has te right to acquire, improve and develop work potential in accordance with his/her talents, interests and abilities.Every worker has the right to be protected by:

a. Occupational health and safety

b. Morality and decency; and

c. Treatment that is in line with human dignity and values

d. Every worker has the right to form and become a unionmember. (Legal basis, Law No. 13 of 2003 on Manpower and Law No. 21 of 2000 on Trade Unions).

2. Workers' basic rights to social security and occupational safety and health (OSH).

Each worker and his her family shall be entitled to social security of labor which includes:

a. Accident insurance;

b. Life insurance;

c. Pension plan;

d. Health care insurance.

Occupational safety and health has the right to ask the employers for all safety and health requirements; declare an objection to a job in which the required occupational safety and health conditions as well as personal protective equipment are in doubt. (Legal Basis, Law No. 13 of 2003 on Manpower, Law No. 3 of 1992 on Workers Social Security (Jamsostek), Ministrial Decree of Manpower No. 04 of 1993 on Religious Holidays Allowance and Ministrial Decree of Manpower No. 01 Year 1998 on the Implementation of Health Care for the workers with Better Benefits from the Basic Health Insurance Security Guarantee Packages of Labor Law No. 1 of 1970 on Occupational Safety, Presidential Decree No. 22 of 1993 on Diseases Arising from Working Relationship, Presidential Decree No. 14 of 1993 on the Implementation of Workers Social Security. [9]

- The Basic Right of Workers on the Protection of Wages

Every worker has the right to earn an income that fulfills a decent living for humanity. The minimum allowance only applies to workers who have a working period of 1 year. Review of the amount of workers' wages with more than 1 (one) year working period. Employers in setting wages should not discriminate between male and female laborers for an equal work. Employers are obliged to pay wages to laborers once they are sick that they can not do their work, and the employer is obliged to pay the wage to the laborer if the 
worker does not come to work because of the following matters:

1. Workers are married, paid for 3 (three) days;

2. To marry off his/her child, paid for 2 (two) days;

3. Circumsize his/her child, paid for 2 (two) days;

4. Baptize his/her child, paid for 2 (two) days;

5. Wife gives a birth or is miscarriage, paid for 2 (two) days;

6. Husband/Wife, Parent/Parent or child/son-in-law dies, paid for 2 (two) days;

7. A family member in one house dies, paid for 1 (one) day.

8. Employers are obliged to pay the wages that are usually paid to workers who can not do their work because they are carrying out state obligations.

(Legal basis of Government Regulation No. 8 of 1981 concerning wage protection, and Regulation of the Minister of Manpower No. 01 of 1999 on minimum wages).

Each employer is obliged to implement the provisions of working time as follows:

1. 7 (seven) hours 1 (one) day and 40 (forty) hours 1 (one) week for 6 (six) working days in 1 (one) week; or

2. 8 (eight) hours 1 (days) and 40 (forty) hours 1 (one) week for 5 (five) working days 1 (one) week. [10]

3. The Basic Right of Workers to make Collective Labor Convenant $(P K B)$.

Trade unions/labor unions, federations and confederations of trade unions that already have a record number have the right to: Create a Collective Labor Convenant with Employers. This Collective Labor Convenant $(P K B)$ is drawn up and implemented in a deliberation between the Employers and the Labor Union witnessed by the Government, in this case is the local Department of Manpower. And the CLA is written in Latin and in Bahasa Indonesia. [11]

- $\quad$ Basic Rights to strike

Strike sas a basic right of workers/laborers and trade/labor unions are conducted legally, orderly and peacefully due to the failure of the negotiations. At least within 7 (seven) working days before the strike is carried out, workers/laborers and trade unions/labor unions shall notify to employers and agencies responsible for local employment in written. In the event of a strike by a worker/laborer not being a member of a trade union/labor union, the notice shall be signed by the workers representative appointed as the coordinator, or the person in charge of the strike. Anyone can not prevent workers unions/labor unions to use the right to strike legally, orderly and peacefully. Anyone is prohibited from making arrests and/or detentions towards workers and workers union officicer who take a strike legally, orderly, and peacefully in accordance with applicable laws and regulations. (Legal basis of Law No. 13 of 2003 on Manpower, and Ministrial Decree of Manpower and Transmigration No. 23 of 2003 on Legal Strikes of Illegal Strikes).

- $\quad$ Female Workers' Special Basic Rights
Female workers under the age of 18 (eighteen) years are prohibited from employing between 23.00 and 07.00. Employers are prohibited to employ pregnant women workers/laborers who, according to the doctor's information, are dangerous to the health and safety of his or her womb or what to do when working between 23.00 s.d. at 07.00 . Employers who employ women workers between 23.00.s.d. at 07.00 must:

1. Provide nutritious food and drink; and

2.Maintain morality and security during in the workplace.

3. In periods of menstruation, pregnancy, childbirth, miscarriage, breastfeeding the baby and others.

- Workers' basic rights are protected against the termination of employment

Employers, workers/laborers, labor unions and the government, with all efforts should endeavor to avoid termination of employment. In the case of all efforts have been made, but termination of employment is inevitable, then the intention of employment termination shall be negotiated by the employers and trade/labor unions or with workers/ laborers if they are not a member of a trade union/labor union (Legal basis of Minister of Manpower Regulation No. 03 of 1989 on Prohibition of Employment Termination for female workers).

- $\quad$ The protection of natural rights

In principle, the worker or laborer is a very valuable asset as a major factor in improving the productivity and performance of a business unit/company/workplace agency, affect the level of welfare of the household where the worker is working. Therefore, they must have protection for both male and female workers. In fact, however, the protection has not been adequately addressed, particularly to non-formal or informal workers as well as to women workers. [12]

Worker is a generic applicable to various employment status, which they do as a consequence This worker status needs to be protected by the State in the system of applicable legislation without distinguishing the type and status of work. However, the legal protection is attached to his/her profession as a worker/laborer.

As what has been described earlier that the basic rights of workers must be distinguished by the workers' natural rights. Natural rights is related to human rights for the outsiders due to their nature as human beings. The National and International law that provides guarantees to workers or laborers are described as follows:

1) The 1945 Constitution in Article 27 (2) and 28

2) Law no. 13 of 2003 on Manpower; Article 76: Female workers are prohibited from employment at 23.00 s.d. 7:00 if:

a. Being less than 18 years old

b. Pregnant which according to the doctor's information is dangerous to the health and safety of the womb or herself

c. Provide nutritious food and drinks 


\section{d. Maintain decency and security during work}

\section{- $\quad$ Social Security}

Talking about social security, it can be traced in the provisions of applicable legislation such as: Article $28 \mathrm{H}$ of the 1945 Constitution (second amendment) states that: "Every person shall have the right to social security which enables his complete development as a dignified humanity" Article 34 paragraph (2) of the 1945 Constitution (fourth amendment), that "the State develops social security system for all people and empowers the weak and incapable ones in accordance with human dignity".

How is the Legal Relationship Model Between Outsourcing Companies, Outsourcing Workers and Employers?The model of legal relations between the three elements that are mutually tied to each other. Where the Outsorcing Company, the workers/labirers, and the company of the respective work providers have the deed of establishment and other requirements as arranged in Law no. 40 Year 2007 on Liability Company. The model of legal relationship in question in the legal requirements is certainly in every company including outsorcing companies have Statutes and Bylaws $(A D / A R T)$. And the operational base of the outsorcing legal company is regulated in such a way how a conductor having that outsourcing business.

In contrast to the outsourced business model with the provider company. The legal relationship model between outsourcing companies with provider companies work, is regulated as follows:

1. Specified-Time Working Convenants Model (PKWT)

Based on Article 1 Sub-Article 2 of the Ministrial Decree of Manpower and Transmigration of the Republic of Indonesia No. KEP: 100 / MEN / VI / 2004 on the Implementation of Specified-Time Working Convenants Model $(P K W T)$, the definition of the Specified-Time Working Convenants is a working convenant between the workers and employers to have a working relationshop within a certain time and for certain workers. The contents of working convenant are usually the subject matter, namely that the work promised, shall not be contrary to the provisions of the law which are coercive or are in the law of public order or with the social order of society. [13]

And the way to make an employment convenant is usually preceded by a period to go before a work convenant called probation. Thus there is an earlier employment convenant with probation. It is only after the employer considers that the worker/laborer is good only to be appointed permanent worker through the employment convenant. [14]

Specified-Time Working Convenants (PKWT), whose workers are often referred to as contractual employees are the working convenants between workers and employers to establish employment within a specified time or for a particular employee. On the Specified-Time Working Convenants, the parties involved are the workers themselves, personally and directly with employers The contents of the work convenant are unified to the individual relationship between workers and employers/companies, for instance regarding to the position, wage/salary of the workers/laborers.

2. Model of Non-Specified- Time Working Convenant (PKWTT)

Based on Article 1 Sub-Article 2 of the Ministrial Decree of Manpower and Transmigration Decree No. 100 / MEN / VI / 2004 on the Implementation of Working Convenants of Uncertain Time, the meaning of the Working Convenant of Uncertain Time is a work convenant between a worker and an employer to establish a working relationship which is fixed. The worker is often called a permanent employee. In addition, written PKWTT can also be made orally and is not required to obtain approval from the relevant working agencies. If the PKWTT is made orally, the company is required to make a letter of appointment for the employee concerned. [15]

When analyzed in an in-depth basis to make this $P K W T T$ is the principle of freedom of contract and good faith as it may require a probation period for a maximum of 3 (three) months. After passing for 3 (three) months, the worker/laborer is automatically becomes the employee of PKWTT/permanent employee. The wishes of the parties embodied in the convenant are the basis of binding on an convenant under French contract law. The will can be expressed in various ways both spoken and written and tying on the parties with all its legal consequences. [16]

The substance contained in the Unspecified Time Work Convenant (PKWTT) based on the Constitutional Court Decree which is subsequently set forth in Article 29 paragraph (2) and paragraph (3) of the Ministrial Decree of Manpower and Transmigration No. 19/2012, (Outsourcing), that its $P K W T$, at least contains:

a. Guarantee of work continuity

b. Guarantees for the fulfillment of the rights of workers/laborers in accordance with the legislation and the convenants; and

c. Guarantees of the calculation of what period of employment shall there be a change in the enterprise of the worker/labor provider to determine wages; as well as other rights such as; The right to leave (yearly) if it has fulfilled the terms of employment, right to social security, pension allowance, right to compensation (compensation for working relationship termination $(P K W T)$, wage adjustment based on accumulated-period of work, and other rights regulated in legislation, and previous $P K W T$.

3. Oral Testament Model

Basically to declare an employment convenant to be valid or not, it shall be obliged to observe the provisions of Article 1320 of the Civil Code stating that 
their Convenant binds itself; Ability to make a commitment; A particular subject matter; A cause which is not prohibited.

Article 52 paragraph (1) of Law no. 13 of 2003 on Manpower also confirms that:

a. Both side convenant; Ability or proficiency to perform legal acts; The existence of the contracted work.

b. The work is not contrary to public interest, morality, and applicable legislation.

Types of work contracts include: Oral form/not written. Although the contract of work is made unwritten, this type of work contract can still bind the workers and employers to carry out the contents of the contract. Of course, this type of work contract has a fatal weakness that if there are some contents of the employment contract that was not implemented by the employer because it is not stated in written that prejudice the worker/laborer.

\section{CONCLUSION}

How if a nation-state is vulnerable to the problems of its citizenship rights such as Indonesia, particularly to deal with outsourced labor relationship with employers (offenders) and providers of employment. It can almost be predicted in a capitalistic economic and political system, liberal democracy as a source of social conflict, especially between workers outsorcing relationship with business service providers, the future will be more turbulent and uncertain.

Law enforcement, legal certainty, low wages, lack of career paths, uncharacteristic social guarantees, labillacles, lack of government-state concerns, make the fate of the workers increasingly marginalized. Thus, an integrated stategovernment role is needed to oversee the production rpcess that is family-friendly, the willingness of employers to share profits with workers/laborers to improve the workers' welfare.

Therefore, the authors conclude (conclusion) that what governments need to do in this case are:

1. Conduct regulatory regulations in the field of Manpower Supervision in isolation.

2. Seek solutions with a popular-minded economic format to reduce the gap between the rich and the poor. 3. Returns all forms of state-government policy in favor of Pancasila and Article 33 (non amendments) of the 1945 Constitution.

\section{REFERENCES}

[1] Http:/ /www. Bnp2tki.go.id/read/9719/Jelang akhir-2014BNP2TKI- Catat -Remitansi-TKI-Capai- Rp- 7747Trilyun, html, accessed on January 23, 2015.

[2]BaharuddinLopa, 1996, Al-Qur'an danHakhakAsasiManusia, Dana Bhakti Prima Yasa, Yogyakarta, page, 121.

[3]SahatDamanik, OutsorcingdanPerjanjianKerja, DSS Publishing, Jakarta,2006, page1.
[4]KolahmanSaragih,

EksistensiLembagaOutsorcingdanPengawasannyaMenur utUndang-undang No. 13 Tahun 2003

TentangKetenagakerjaan, (Tesis), Program Magister IlmuHukum, UniversitasMuhammadiyah, Sumatera utara-Medan, 2010, page1-2.

[5]SakkaPati,(Tesis)

PerlindunganHukumBagiPekerjaRumahTanggaditinjaud ariPerspektifKeadilan, page 186-187.

[6]PenjelasanPasal 66 Undang-Undang No. 13 Tahun 2003, TentangKetenagakerjaan, Lembaran Negara Republik Indonesia Tahun 2003, nomor 4279, page 95.

[7] Http//www.gajimcom/main/tips-karir/untung-rugisistem-201coutsorcing201d, page 1.

[8]KomunitasPekerja Kota Tasikmalaya, 18 Desember 2012, Website internet:https;//www.fecebook.com/permalink,php?id=62 $8735520499620 \&$ story fbid $=646336595406179$, accessed on October 7, 2014.

[9]Anonim, Undang-undangketenagakerjaan, 15 Oktober 2013, Website internet ;https//www facebook.com/parmalinkphp?id=62735520499620\&story -fbid=646336595406179, accessed on October 17, 2014.

[10]SakkaPati,(Tesis)

PerlindunganHukumBagiPekerjaRumahTanggaditinjaud ariPerspektifKeadilan, FakultasHukum,

UniversitasHasanuddin Makassar 2015, page 237.

[11]Surayin, Tanya JawabUndang-Undang No. 13 Tahun 2003, TentangKetenagakerjaan, YaramaWidya, Bandung, 2004, page, 76.

[12]KolahmanSaragih, EksistensiOutsorcingdanPengawasannyaMenurutUndang -Undang No. 13 Tahun 2003, (Tesis),

FakultasHukumUniversitasMuhammaddyah Sumatera Utara- Medan , 2010, page, 33.

[13] ILO ,Perekonomian Informal : TransisiMenujuFormalisasi, SimposiumTripartit InterRegional, Jenewa, 27-29 November 2007,page 27.

[14] H. Koko Kosidin, PerjanjianKerja,PerjanjianPerbirihan,danPeraturanPerusa haan,BandarMaju ,Bandung 1999, page, 24.

[15] F.X. Djumialdji, PerjanjianKerja, BumiAksara, Jakarta, 1997, page, 28.

[16]Suharnoko, HukumPerjanjian, TeoridanAnalisaKasus, Prenada Media Group, Jakarta, 2007, page, 3.

[17]GunartoSuhardi, PerlindunganHukumBagi Para PekerjaKontrakOutsorcing,Andi Offset, Yogyakarta,2006, page 13. 